\title{
Changes of starch composition by postflowering environmental conditions in kernels of maize hybrids with different endosperm hardness ${ }^{\text {is }}$
}

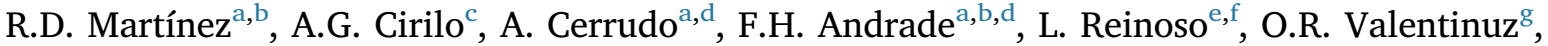 \\ C.N. Balbi ${ }^{\text {h }}$, N.G Izquierdo ${ }^{\mathrm{a}, \mathrm{b}, *}$ \\ ${ }^{\text {a }}$ Facultad de Ciencias Agrarias, Universidad Nacional de Mar del Plata, Ruta $226 \mathrm{~km}$ 73.5, Balcarce, Argentina \\ ${ }^{\mathrm{b}}$ Consejo Nacional de Investigaciones Científicas y Técnicas (CONICET), Argentina \\ c Instituto Nacional de Tecnología Agropecuaria (INTA), Estación Experimental Agropecuaria Pergamino, Ruta 32, Km 4.5-CC 31, Pergamino, Buenos Aires, Argentina \\ d Instituto Nacional de Tecnología Agropecuaria (INTA), Estación Experimental Agropecuaria Balcarce, Ruta 226 Km 73.5, Balcarce, Buenos Aires, Argentina \\ e Instituto Nacional de Tecnología Agropecuaria (INTA), Estación Experimental Agropecuaria Valle Inferior del Río Negro, Ruta 3 Km 971, Viedma, Río Negro, Argentina \\ ${ }^{\mathrm{f}}$ Departamento de Ciencias Exactas, Naturales y de Ingeniería, Universidad Nacional de Rio Negro, Belgrano 526, Viedma, Rio Negro, Argentina \\ ${ }^{g}$ Instituto Nacional de Tecnología Agropecuaria (INTA), Estación Experimental Agropecuaria Paraná, Ruta 11 Km. 12.5, Oro Verde, Entre Ríos, Argentina \\ ${ }^{\text {h }}$ Facultad de Ciencias Agrarias, Universidad Nacional del Nordeste, Sargento Juan Bautista Cabral 2131, Corrientes, Corrientes, Argentina
}

\section{A R T I C L E I N F O}

\section{Keywords:}

Amylose/starch ratio

Location

Sowing date

Minimum temperature

\begin{abstract}
A B S T R A C T
Starch composition of maize grains is of great importance when used in animal feed and many processing industries. Maize production involves hybrids with different kernel composition and hardness, sown at areas that range from subtropical to temperate cold climates. Therefore, it is relevant to understand how the environment influences starch composition. The objective of this work was to analyze the effect of location and sowing date on starch composition of maize grains. Field experiments were carried out at five locations across the argentinean maize-production area during two growing seasons. At each location, two sowing dates and three hybrids differing in endosperm hardness (i.e. semi-dent, a semi-flint and flint) were evaluated. Late sowing dates reduced amylose percentage and amylose/starch ratio. This last variable increased as latitude decreased. Minimum temperature during effective grain filling period explained those latitude and sowing date effects. This finding would be helpful to estimate starch composition of maize kernels to be expected in order to satisfy specific end uses.
\end{abstract}

\section{Introduction}

Kernel hardness is a variable of great significance to maize producers, traders and processors. Kernel hardness is related to bulk density, storability, attack of storage insects and breakage susceptibility, milling characteristics, dry and wet milling yields and production of special foods (Pomeranz et al., 1984). Maize dry milling industry demands high kernel hardness in order to maximize yield of coarse fractions (flaking grits) during grinding (Chandrashekar and Mazhar, 1999; Hill et al., 1991). On the other hand, wet milling market demands intermedium kernel hardness to obtain the major starch yield as possible (Eckhoff, 2004). For animal feed however, hard endosperm reduces digestive action in animals (Rooney and Pflugfelder, 1986), so soft endosperm is preferred.

Grain endosperm is mainly composed of protein and starch. Starch represents about $70 \%$ of the maize endosperm and it consists of two types of carbohydrate chains, amylose and amylopectin. The first one represents about $25 \%$ of starch and has predominantly linear $\alpha-1,4-$ linked glucans, whereas amylopectin has $\alpha$-1,4-linked chains branched extensively with 1,6-linkages (Ball et al., 1996). Starch is contained in granules, called amyloplasts (Sabelli and Larkings, 2009), which are dispersed in a rigid matrix of proteins throughout the endosperm.

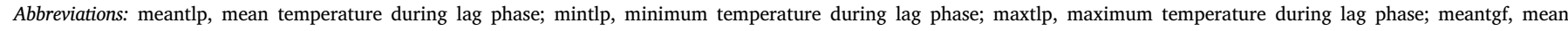

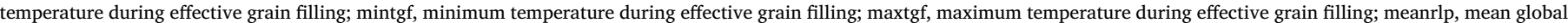

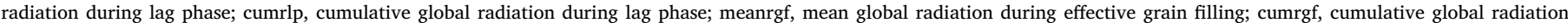

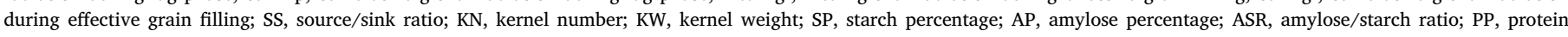
percentage

This study is in partial fulfillment for requirements from the Roberto Dionisio Martínez thesis work to obtain Doctor en Ciencias Agrarias degree (Facultad de Ciencias Agrarias, Universidad Nacional de Mar del Plata, Argentina).

* Corresponding author at: Facultad de Ciencias Agrarias, Universidad Nacional de Mar del Plata, Ruta 226 km 73.5, Balcarce, Argentina.

E-mail address: izquierdo.natalia@inta.gob.ar (N.G. Izquierdo). 
Table 1

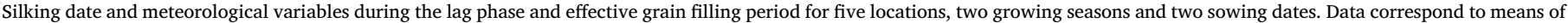
daily mean, minimum and maximum temperatures and mean and cumulative solar radiation (average for three hybrids).

\begin{tabular}{|c|c|c|c|c|c|c|c|c|c|c|c|c|c|}
\hline \multirow{4}{*}{ Location } & \multirow{4}{*}{ Year } & \multirow{4}{*}{ Sowing date } & \multirow{4}{*}{ Silking } & \multicolumn{6}{|c|}{ Temperature } & \multicolumn{4}{|c|}{ Global Radiation } \\
\hline & & & & \multicolumn{3}{|c|}{ Lag phase } & \multicolumn{3}{|c|}{ Effective grain filling } & \multicolumn{2}{|c|}{ Lag phase } & \multicolumn{2}{|c|}{ Effective grain filling } \\
\hline & & & & Mean & Minimum & Maximum & Mean & Minimum & Maximum & Mean & Cumulative & Mean & Cumulative \\
\hline & & & & \multicolumn{6}{|l|}{$\left({ }^{\circ} \mathrm{C}\right)$} & \multicolumn{4}{|c|}{$\left(\mathrm{MJ} \mathrm{m}^{-2}\right)$} \\
\hline \multirow[t]{3}{*}{ Corrientes } & 2009-10 & Early & $12 / 10 / 2009$ & 26.1 & 21.3 & 30.9 & 27.4 & 22.6 & 32.2 & 20.7 & 269.0 & 22.9 & 779.9 \\
\hline & & Late & $3 / 1 / 2010$ & 27.1 & 21.9 & 32.4 & 23.3 & 18.1 & 28.6 & 21.7 & 259.8 & 15.7 & 691.7 \\
\hline & $2010-11^{\mathrm{a}}$ & Early & $12 / 6 / 2010$ & 24.6 & 18.6 & 30.6 & 26.5 & 20.6 & 32.5 & 24.3 & 316.1 & 23.3 & 814.2 \\
\hline \multirow[t]{4}{*}{ Paraná } & 2009-10 & Early & $12 / 17 / 2009$ & 25.2 & 19.6 & 30.7 & 25.1 & 19.5 & 30.7 & 19.9 & 259.2 & 22.2 & 821.3 \\
\hline & & Late & $2 / 9 / 2010$ & 25.4 & 20.4 & 30.3 & 23.1 & 17.7 & 28.5 & 18.2 & 236.9 & 18.5 & 757.1 \\
\hline & 2010-11 & Early & $12 / 28 / 2010$ & 26.1 & 19.6 & 32.5 & 25.1 & 18.9 & 31.3 & 24.3 & 316.5 & 22.5 & 810.8 \\
\hline & & Late & $2 / 15 / 2011$ & 23.8 & 18.8 & 28.8 & 20.9 & 14.8 & 27.0 & 18.2 & 254.7 & 19.4 & 990.7 \\
\hline \multirow[t]{4}{*}{ Pergamino } & 2009-10 & Early & $12 / 21 / 2009$ & 23.6 & 18.0 & 29.3 & 23.9 & 17.6 & 30.1 & 21.4 & 320.9 & 23.1 & 1064.3 \\
\hline & & Late & $2 / 15 / 2010$ & 20.9 & 15.3 & 26.5 & 19.2 & 12.0 & 26.4 & 18.6 & 315.5 & 15.7 & 782.9 \\
\hline & 2010-11 & Early & $1 / 2 / 2011$ & 23.0 & 15.8 & 30.3 & 21.1 & 14.3 & 28.0 & 24.4 & 365.3 & 22.7 & 974.3 \\
\hline & & Late & $2 / 12 / 2011$ & 21.4 & 15.4 & 27.4 & 17.8 & 9.4 & 26.2 & 20.4 & 348.7 & 17.1 & 838.3 \\
\hline \multirow[t]{4}{*}{ Balcarce } & 2009-10 & Early & $1 / 6 / 2010$ & 21.5 & 13.8 & 29.2 & 21.2 & 15.3 & 26.9 & 23.0 & 367.3 & 18.6 & 930.2 \\
\hline & & Late & $2 / 15 / 2010$ & 18.8 & 13.5 & 24.1 & 16.7 & 11.1 & 22.2 & 16.9 & 354.2 & 12.6 & 567.3 \\
\hline & 2010-11 & Early & $1 / 11 / 2011$ & 22.5 & 15.4 & 29.6 & 20.9 & 15.0 & 26.7 & 24.1 & 386.1 & 19.4 & 930.7 \\
\hline & & Late & $2 / 11 / 2011$ & 20.8 & 15.0 & 26.5 & 18.5 & 11.6 & 25.3 & 19.4 & 349.6 & 14.9 & 760.5 \\
\hline \multirow[t]{4}{*}{ Viedma } & 2009-10 & Early & $1 / 15 / 2010$ & 25.0 & 17.4 & 32.5 & 19.8 & 13.5 & 26.1 & 27.2 & 380.8 & 19.4 & 1143.6 \\
\hline & & Late & $2 / 16 / 2010$ & 20.4 & 14.7 & 25.9 & 16.2 & 9.8 & 22.5 & 18.7 & 356.1 & 14.8 & 724.5 \\
\hline & 2010-11 & Early & $2 / 1 / 2011$ & 22.8 & 14.0 & 31.5 & 19.4 & 12.1 & 26.7 & 26.7 & 400.8 & 19.1 & 1030.9 \\
\hline & & Late & $2 / 18 / 2011$ & 21.7 & 14.7 & 28.6 & 17.5 & 10.0 & 24.9 & 20.6 & 371.5 & 17.1 & 683.1 \\
\hline
\end{tabular}

a Only early sowing date was carried out this year at this location.

Starch and protein percentage are usually related and there is abundant evidence for a negative starch/protein relationship (e.g. Seebauer et al., 2010). Robutti et al. (2000) found that starch concentration was negatively correlated with kernel hardness, and horny endosperm presented higher amylose content than floury endosperm. Endosperms with high amylose/starch ratio would be more compressible and therefore become denser and harder at harvest than endosperms with a high proportion of amylopectin (Dombrink-Kurtzman and Knutson, 1997).

Kernel hardness is an intrinsic property of the genotype (Duarte et al., 2005) but it is also modulated by the crop growing conditions (Cirilo et al., 2003, 2011; Eyhérabide et al., 2004; Tanaka et al., 2005). The environment could alter starch composition by acting on enzymes of the biosynthetic starch pathway i.e.: those involved in substrate production, the elongation of the $\alpha-1,4$-glucan chains and their branching, and the maintenance of granule crystallinity (Beckles and Thitisaksakul, 2014). In wheat and barley, increases in temperature during grain filling increased kernel amylose concentration (Hurkman et al., 2003; Savin and Nicolas, 1999; Shi et al., 1994). During starch synthesis, the starch branching enzyme branches the chain to produce amylopectin (James et al., 2003). Lenihan et al. (2005) proposed that changes in the amylose/starch ratio in maize as result of differences at growing environments could be explained by the direct effect of temperature on the enzymatic activity in endosperm cells. Increases in temperature could decrease total starch branching enzyme activity increasing amylose/starch.

Starch content and composition, as well as other kernel components, are defined during the grain filling period. Delayed sowings in a temperate climate caused lower rates of grain filling, shorter duration of grain filling, and a decrease in final weight of kernels (Cirilo and Andrade, 1996). Actis (2007) found that starch percentage in maize kernels had lower variation through environments than amylose/starch ratio. In that work, kernels from late sowing dates, with lower temperatures during grain filling, presented less amylose concentration than those from early sowing dates.

Argentinean maize production areas range from subtropical to temperate cold climates (Hall et al., 1992), and constitute with the
Corn Belt of the USA, Europe and Northwest China the temperate maize mega-environments (Fischer et al., 2014). Locations and sowing dates modify environmental conditions (i.e. temperature and incident radiation) during grain filling which in turn could affect starch composition. Understanding how growth conditions determine grain starch composition is essential for the development of production strategies with the aim of obtaining convenient grain quality in maize. So, the objective of our research was to analyze the effect of location and sowing date on starch composition in maize hybrids differing in endosperm hardness.

\section{Materials and methods}

\subsection{Experimental design and growing conditions}

Field experiments were carried out at five locations across the argentinean maize-production area: Viedma $\left(40^{\circ} 49^{\prime} \mathrm{LS}\right)$, Balcarce $\left(37^{\circ}\right.$ $\left.50^{\prime} \mathrm{LS}\right)$, Pergamino ( $\left.33^{\circ} 53^{\prime} \mathrm{LS}\right)$, Paraná ( $\left.31^{\circ} 43^{\prime} \mathrm{LS}\right)$ and Corrientes $\left(27^{\circ}\right.$ $27^{\prime} \mathrm{LS}$ ) during two growing seasons (2009-10 and 2010-11). Locations vary in air temperature and incident global solar radiation; thus, they were considered as a source of variation. Locations also vary in soil type: fine silty clay thermic Aridic Gypsiustert (Viedma), silty clay loam Typic Argiudoll (Balcarce), silty clay loam Typic Argiudoll (Pergamino), fine mixed thermic Aquic Argiudoll (Paraná) and fine clay loamy mixed Hyperthermic Udipsamments (Corrientes). At each location, treatments (sowing date and hybrid type) were arranged in a split-plot design with three replicates. Sowing dates were assigned to main plots, whereas hybrids were assigned to the sub-plots. Sub-plots had $35 \mathrm{~m}^{2}$ (5 rows, $0.7 \mathrm{~m}$ apart, and $10 \mathrm{~m}$ long). Sowing dates were mid-October (early) and mid-December (late). Hybrids were: a semident type with high yield potential (Dk190, Monsanto Argentina S.A.), a semi-flint hybrid with high yield potential but unstable in flint type expression (Cóndor, Syngenta Agro S.A.) and an hybrid with limited grain yield potential but strong flint type expression (M522, Dow AgroSciences S.A.). These hybrids are similar in cycle length having a relative maturity around 121 , for this reason there were no differences among hybrids silking date or grain filling duration.

Plots were hand-planted at three seeds per hill and thinned to the 
Table 2

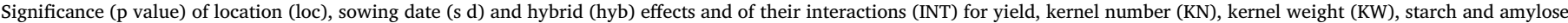

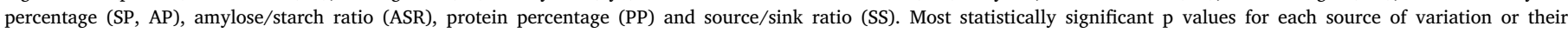
combination are shown in bold type.

\begin{tabular}{|c|c|c|c|c|c|c|c|c|}
\hline & Yield & $\mathrm{KN}$ & KW & SS & SP & $\mathrm{AP}$ & ASR & PP \\
\hline (Intercept) & $<0.0001$ & $<0.0001$ & $<0.0001$ & $<0.0001$ & $<0.0001$ & $<0.0001$ & $<0.0001$ & $<0.0001$ \\
\hline Location & $<0.0001$ & $<0.0001$ & 0.0003 & 0.3573 & 0.4807 & 0.0026 & 0.0001 & 0.0019 \\
\hline Sowing date & $<0.0001$ & $<0.0001$ & $<0.0001$ & 0.2354 & 0.3002 & 0.0113 & 0.0423 & 0.0450 \\
\hline Hybrid & $<0.0001$ & $<0.0001$ & $<0.0001$ & $<0.0001$ & 0.2462 & $<0.0001$ & $<0.0001$ & $<0.0001$ \\
\hline loc*s d INT & 0.0337 & 0.0001 & 0.0034 & 0.0007 & 0.0443 & 0.7743 & 0.0537 & 0.0676 \\
\hline loc*hyb INT & 0.0135 & $<0.0001$ & $<0.0001$ & 0.0020 & 0.0350 & 0.2754 & 0.3889 & 0.0001 \\
\hline s d*hyb INT & 0.3889 & 0.1201 & 0.0001 & 0.0456 & 0.0926 & 0.5324 & 0.8187 & 0.0333 \\
\hline loc*s d*hyb INT & 0.0380 & 0.4246 & 0.0113 & 0.9229 & 0.0978 & 0.2644 & 0.0303 & 0.6323 \\
\hline
\end{tabular}

desired plant population $\left(7.5 \mathrm{pl} . \mathrm{m}^{-2}\right)$ at V3. Water stress was prevented by irrigation. Insects, weeds and diseases were appropriately controlled. Air temperature and incident solar global radiation data were obtained from standard weather stations installed not farther than $500 \mathrm{~m}$ from each experimental site. The combination of locations and sowing dates allowed to obtain a wide range of meteorological conditions during grain filling (Table 1). Pre-sowing phosphorus and sulfur contents were above 18 and $6 . \mathrm{mg} \cdot \mathrm{kg}^{-1}$ respectively. Soil pH increased with latitude from 5.5 to 8.0. The content of organic matter had a similar trend, increasing from 13.5 to $54.7 . \mathrm{g} \cdot \mathrm{kg}^{-1}$ from Corrientes to Balcarce, and slightly decreasing again in Viedma. Soil samples at two strata $(0-0.20 \mathrm{~m}$ and $0.20-0.60 \mathrm{~m})$ were taken to define the crop fertilization rate. Consequently, fertilizer was added at V6 stage in order to avoid nutrient limitations according to local recommendations in each location for a target yield of $10 \mathrm{Mg} \cdot \mathrm{ha}^{-1}$.

Phenological stages were determined according to Ritchie and Hanway (1982). Dates of silking (50\% of plants with at least one visible stigma; Table 1$)$, end of lag phase $\left(220^{\circ} \mathrm{C}\right.$ day after silking using a base temperature of $8{ }^{\circ} \mathrm{C}$, Maddonni et al., 1998) and physiological maturity $(50 \%$ of plants with kernels at central portion of the ear between $75 \%$ of milk-line and black layer) were registered at each main plot and the three replicates were averaged.

\subsection{Sample processing and chemical determinations}

Five plants per plot were sampled at silking and at physiological maturity in order to determine the amount of dry matter accumulated at each moment. Plants were oven dried at $60^{\circ} \mathrm{C}$. At harvest time (approx. 20\% grain moisture), grain yield and its components were determined from plants harvested in $5 \mathrm{~m}^{2}$ of the central rows of each plot. Ears samples were threshed and kernels were weighed. A subsample of 500 kernels per plot was weighed to determine mean kernel weight in a dry basis. Kernel number per $\mathrm{m}^{2}$ was calculated from the total weight of grains $\mathrm{m}^{2}$ and average grain weight on a dry basis. Post-silking source/sink ratio (in mg per kernel) was calculated as the ratio between post-silking biomass accumulation and kernel number at harvest per unit area (Cirilo et al., 2011). This ratio was used as an estimator of photoassimilate availability per growing kernel during grain filling. The ratio overestimated the aboveground plant biomass increase per kernel during the effective grain-filling period since it included the lag phase during which the kernels do not grow (Cirilo and Andrade, 1996; Borrás et al., 2002).

Endosperm amylose concentration was determined by the Knutson method (1986) with modifications from Robutti et al. (2000). Endosperm starch concentration was determined as proposed by Dubois et al. (1956). Nitrogen in the grain was also determined by the Kjeldahl methodology (Nelson and Sommers, 1973) and the amount of protein was estimated as $\mathrm{N}$ value multiplied by 6.25 and it was expressed as percentage of dry kernel weight. All chemical determinations were carried out in the Laboratorio de Calidad de Cereales from INTA Pergamino and in the Laboratorio de Ecofisiología from Unidad
Integrada Balcarce, Argentina.

\subsection{Data analysis}

Data analysis was performed using R Commander package (Fox, 2005), and consisted in three steps:

Combined analyses of variance over locations and years data was made to evaluate the effects of hybrids, location, sowing date and their interactions on response variables. Locations and years were assumed as fixed effects. Year, however, was not analyzed as source of variation because experiments were not carried out to prove this variable. Even temperature and radiation records were similar for both growing seasons (Table 1). The Tukey mean comparison test was applied to determine significant differences $(\mathrm{p}<0.05)$.

Principal components analysis (PCA) was carried out to find associations among crop and environmental variables. Pearson correlation coefficients were also calculated to evaluate the associations among environmental variables, source/sink ratio and starch composition.

When the correlation coefficient was significant for any variable, simple linear regressions were performed for each hybrid. Resulting models were evaluated in terms of the regression determination coefficient. Afterthat, a fit model to each hybrid was carried out and intercepts and slopes were compared using dummy variables through a multiple regression procedure.

\section{Results}

\subsection{Analyses of variance for yield and grain components}

Yield varied from 4000 to $14836 \mathrm{~kg} \mathrm{ha}^{-1}$ showing a significant location*sowing date*hybrid interaction (Table 2). In general, Corrientes and Paraná showed lower yield than the other locations (Fig. 1). Early sowing dates presented higher yield than late sowing dates in all locations ( $\mathrm{p} \leq$ 0.0335), except in Corrientes. The hybrid Dk190 had higher yield than M522 in Balcarce, Paraná and in late sowings in Corrientes and Viedma ( $p \leq 0.0123)$. In all cases, the yield of hybrid Cóndor did not statistically differ from those of the other hybrids.

Kernel number showed location*sowing date and location*hybrid interaction (Table 2). Corrientes showed average lower kernel number than the other locations (Fig. 1). Late sowing dates significantly reduced kernel number $(\mathrm{p} \leq 0.0674)$, except in Viedma where did not show differences. Hybrids Dk190 and Cóndor showed, more kernel number than M522, except at Corrientes where Cóndor had the lowest kernel number $(\mathrm{p}=0.0019)$.

Kernel weight varied from 173 to $335 \mathrm{~g} 1000$ grains $^{-1}$ showing a location*sowing date*hybrid interaction (Table 2). Corrientes showed in average higher kernel weight than the other locations (Fig. 1). Early sowing dates showed higher kernel weight than late sowings at Balcarce and Viedma, without differences in other locations. Hybrid M522 showed higher kernel weight than hybrid Dk190 across locations 


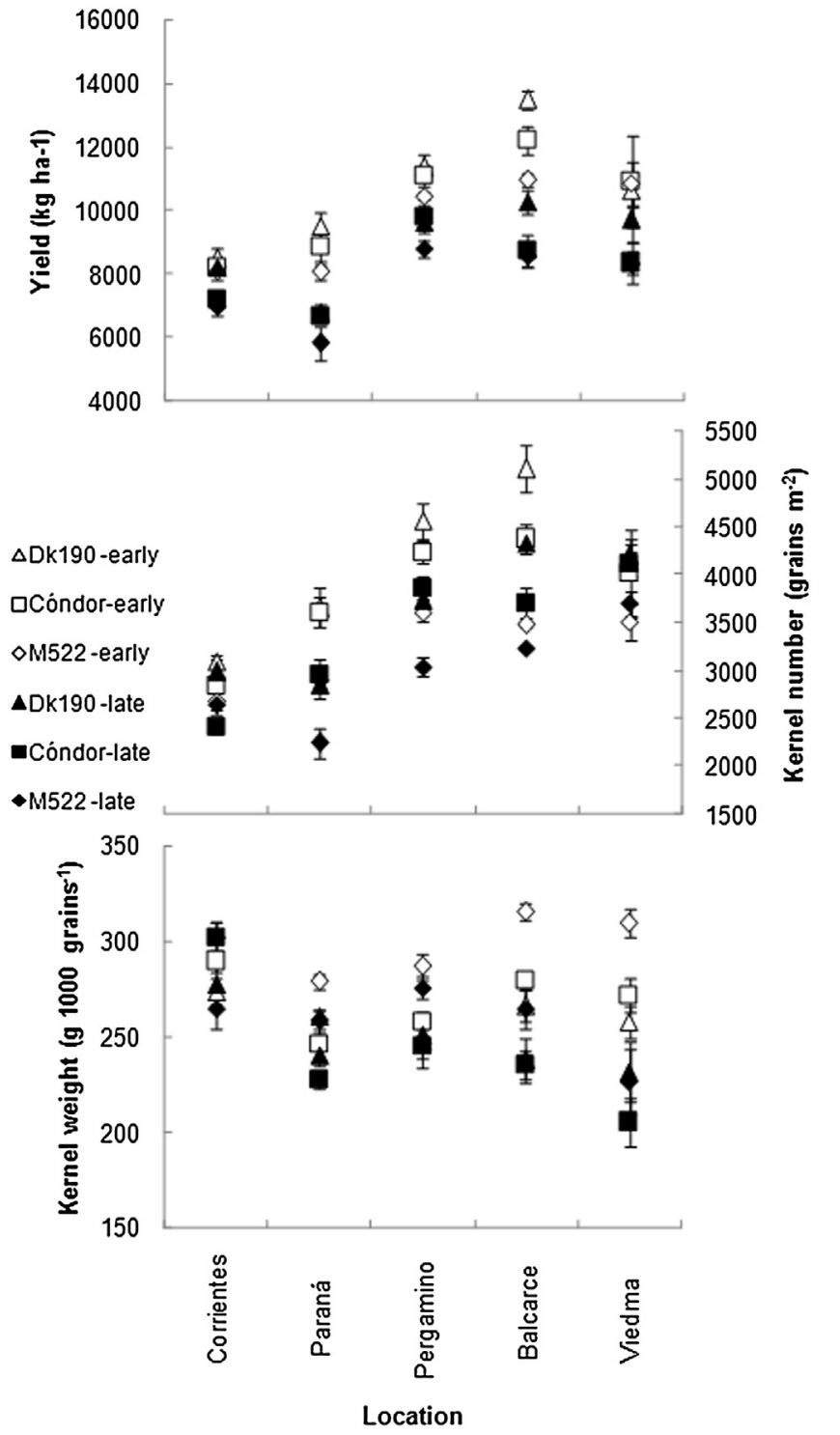

Fig 1. Yield, kernel number and kernel weight for five locations, two sowing dates (early and late) and three hybrids differing in endosperm hardness (semi-dent Dk190, semi-flint Cóndor and flint M522). Symbols represent average values for main plots and bars indicate the standard error.

( $\mathrm{p} \leq$ 0.0186), except at late sowings in Corrientes. Corrientes showed the highest stability in yield, kernel number and kernel weight across sowing dates and hybrids (Fig. 1).

Source/sink ratio from silking to physiological maturity showed a location*sowing date and a location*hybrid interactions (Table 2). At early sowing dates, Balcarce showed greater source/sink ratio than the other locations ( $\mathrm{p} \leq$ 0.0286; Fig. 2); but at late sowing dates showed the lowest source/sink ratio ( $\mathrm{p} \leq$ 0.0487). Hybrid M522 showed the highest source/sink ratio at Pergamino and Balcarce ( $\mathrm{p} \leq 0.0607)$. In Paraná, this hybrid showed higher source/sink ratio than Cóndor and did not differ from Dk190. In Corrientes, Cóndor showed the highest source/sink ratio $(\mathrm{p}=0.0001)$.

Kernel starch concentration varied from 58.5 to $76.8 \%$ showing location*sowing date and sowing date* hybrid interactions (Table 2). Mean values for locations only differed in Cóndor hybrid, when Balcarce and Pergamino showed higher starch percentage than Cor-

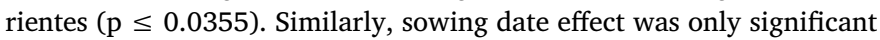
at Paraná and Viedma (Fig. 3), where late sowing date decreased starch percentage ( $\mathrm{p} \leq 0.0314$ ). Hybrid $\mathrm{Dk} 190$ presented greater starch percentage than Cóndor in Viedma, but Cóndor showed higher starch

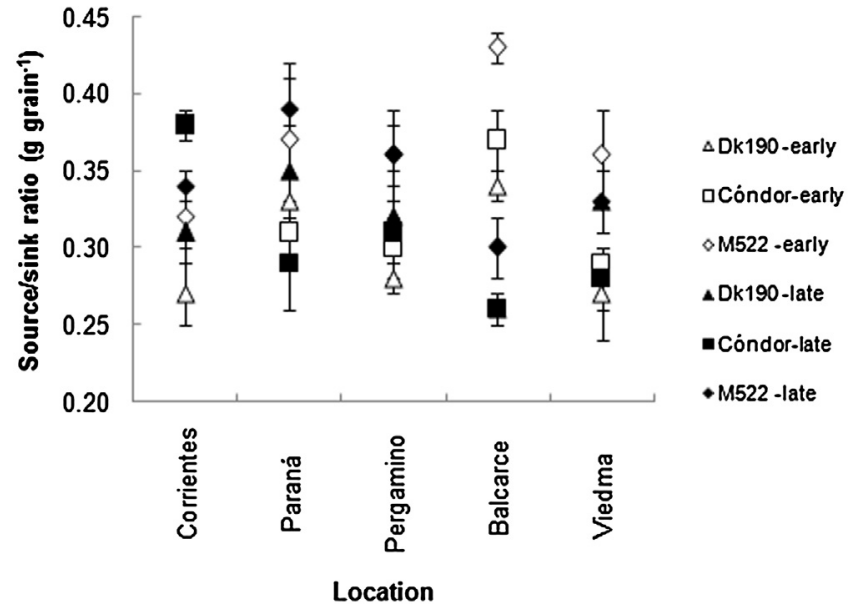

Fig. 2. Source/sink ratio (SS) for five locations, two sowing dates (early and late) and three hybrids differing in endosperm hardness (semi-dent Dk190, semi-flint Cóndor and flint M522). Symbols represent average values for main plots and bars indicate the standard error. The SS was calculated as plant biomass increase per kernel during the post-flowering period.

percentage than the other hybrids in Corrientes.

For amylose percentage, no significant interactions among factors were detected (Table 2). Corrientes presented higher amylose percentage than the other locations (Fig. 3). In all cases, late sowing dates decreased amylose percentage ( $\mathrm{p} \leq 0.0050$ ). The hybrid Dk190 showed lower amylose percentage than the other hybrids $(\mathrm{p} \leq 0.0010)$.

Amylose/starch ratio showed a location*sowing date*hybrid interaction (Table 2, Fig. 2). Corrientes showed greater amylose/starch ratio than the other locations, mainly at early sowing dates (Fig. 3). Delaying sowing date generally decreased amylose/starch ratio in Balcarce and Pergamino ( $\mathrm{p} \leq$ 0.0896). M522 had more amylose/starch ratio than Dk190 hybrid, except in late sowings in Corrientes when Cóndor had the highest ratio ( $\mathrm{p} \leq 0.0031)$.

Protein percentage showed a location*hybrid and sowing date*hybrid interactions (Table 2). Paraná presented the lowest protein percentages, mainly in the Dk190 hybrid ( $\mathrm{s} \leq 0.0414)$. In M522, delaying sowing date reduced protein concentration ( $\mathrm{p} \leq 0.0003)$. In general, hybrids M522 and Dk190 showed the highest and lowest protein concentration ( $\mathrm{p} \leq 0.0205)$.

\subsection{Effect of environmental variables on starch composition}

The first and second principal components contributed 39.6 and $20.0 \%$ of the total variation, respectively, so $59.6 \%$ of the total variation was explained by the first two principal components (Fig. 4). Yield was more related to kernel number than to kernel weight. Starch percentage was associated with yield, kernel number and cumulative incident radiation during the lag phase, and showed a highly significant negative association with minimum temperature during this period. Kernel weight showed a positive association with source/sink ratio, maximum temperature during the lag phase and mean incident radiation during the effective grain filling. Amylose/ starch ratio was positively associated with minimum temperature during the effective grain filling period and with minimum temperature during the lag phase. Amylose/starch ratio was directly associated with amylose percentage and negatively associated with starch percentage.

Correlation coefficients of environmental variables with starch percentage were lower in comparison to those obtained with amylose percentage and amylose/starch ratio. Correlation coefficient with source/sink ratio was low for starch percentage and composition. Starch percentage showed the highest correlation value with minimum temperature during lag phase period (Fig. $5 ; \mathrm{p} \leq 0.07$ ). Both amylose percentage and amylose/starch ratio showed the highest correlation 


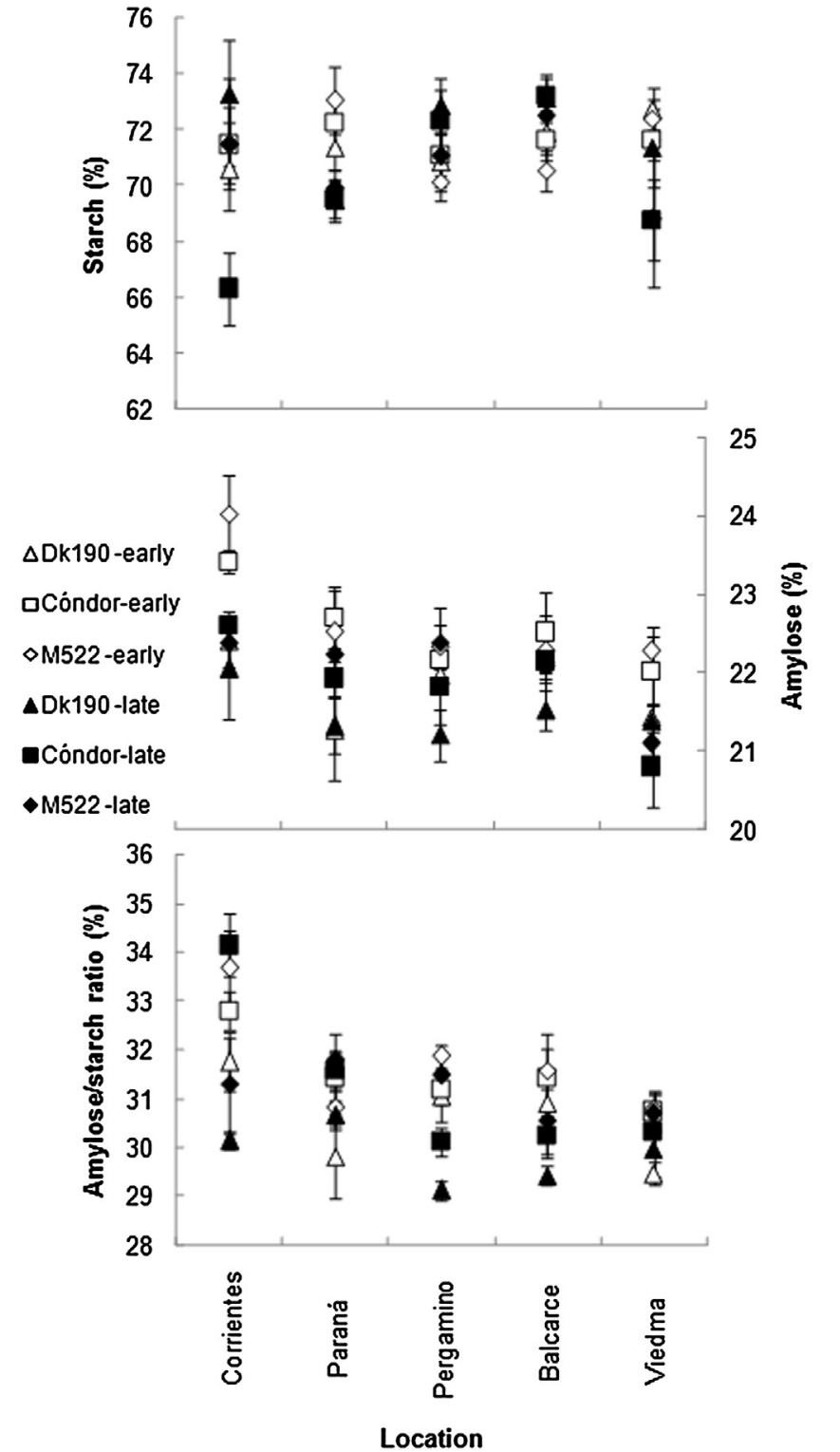

Fig. 3. Starch percentage, amylose percentage and amylose/starch ratio for five locations, two sowing dates (early and late) and three hybrids differing in endosperm hardness (semi-dent Dk190, semi-flint Cóndor and flint M522). Symbols represent average values for main plots and bars indicate the standard error.

coefficients with minimum temperature during the effective grain filling period ( $p \leq 0.0001$ ). Starch percentage presented no significant regressions with any of the analyzed variables ( $\mathrm{p} \geq 0.1635)$.

According to the PCA and Pearson correlation coefficients, increases in minimum temperature from 9 to $23^{\circ} \mathrm{C}$ during the effective grain filling period increased amylose percentage about 4 points $(\mathrm{p} \leq 0.0064)$ and amylose/starch ratio in all hybrids ( $\mathrm{p} \leq 0.0004$, Fig. 6). Although slopes and intercepts did not statistically differ among hybrids ( $\mathrm{p} \geq 0.1577$ ), Dk190 had a slope slightly lower than the other hybrids ( 0.06 vs. 0.15 in amylose percentage and 0.16 vs. 0.22 in amylose/starch ratio). However a unique equation accounted for the $36.2 \%$ of variability in amylose percentage and $52.5 \%$ in amylose/ starch ratio among hybrids and environments.

\section{Discussion}

Location and sowing date modified yield components and starch composition. Among locations, those at low latitude showed higher kernel weight than those at high latitude. Kernel weight changes in a

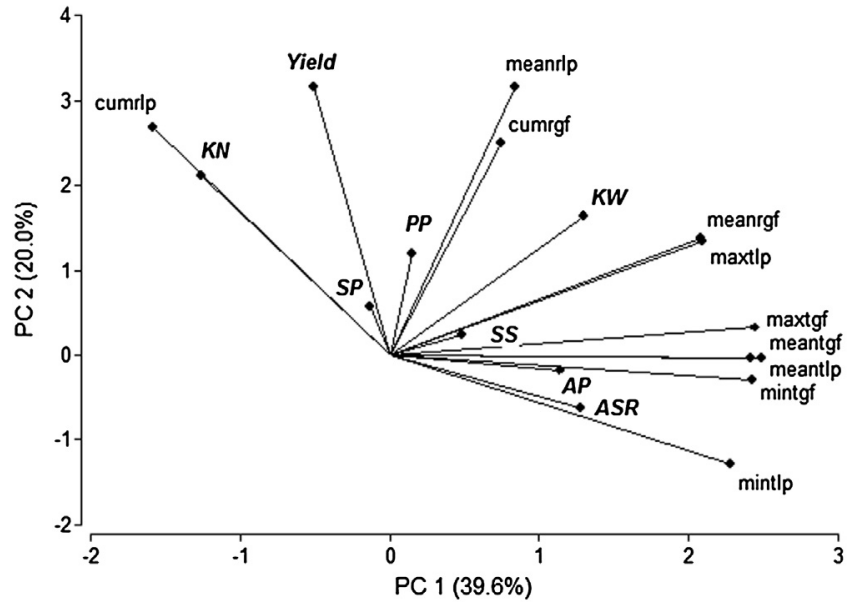

Fig. 4. Biplot from Principal Component Analysis showing associations between crop variables and source/sink ratio (in capital and italic letter) and environmental variables during post-flowering period.

particular location were mainly attributed to sowing date effects, with heavier kernels in early sowings dates because of favorable weather conditions during grain filling (Cirilo and Andrade, 1994). In fact, delays in sowing date exposed the crop to low incident radiation from silking to physiological maturity (Table 1 ). This caused a decrease in final kernel weight maybe due to lower rates and shorter duration of grain filling (Cirilo and Andrade, 1996). In the PCA of the present work, kernel weight was associated with source/sink ratio as in previous works (Borrás et al., 2002; Cirilo and Andrade, 1996). Kernels obtained in early sowings showed higher amylose percentage and higher amylose/starch ratio than those obtained at late sowings, in agreement with previous findings reported by Actis (2007). Moreover, decreases in latitude also resulted in increases in amylose percentage and amylose/ starch ratio. These latitude and sowing date effects were related to changes in temperature during grain filling. Environmental effect on kernel number and kernel weight was previously analyzed, but their effect on starch composition constitutes a novel aspect of this research.

Locations at low latitudes showed lower yields, lower starch percentage, higher kernel weight and higher amylose percentage than locations at high latitude. Locations at low latitudes showed higher temperatures during lag phases and effective grain filing period than high latitude locations (Table 1). High kernel numbers were associated with low minimum temperatures and high cumulative incident radiation during lag phase as in previous studies (Andrade et al., 2000; Cantarero et al., 1999). Similar environmental conditions allowed to obtain high kernel starch percentage which could be due to an increase in the number of endosperm cells (Commuri and Jones, 1999) and starch granules (Jones et al., 1996).

Variations found in starch composition, however, were more closely related to temperature changes during the grain filling period than to assimilate availability per grain in that period. These results support the theory proposed by Lenihan et al. (2005) which hypothesize that increases in temperature reduces starch branching enzyme activity increasing relative amylose deposition in the endosperm of maize kernels. So, increases in amylose/starch ratio in response to temperature would be attributed to a direct effect of temperature on amylopectin synthesis.

Increases in temperature increased amylose percentage and amylose/starch ratio in contrast to that reported by Fergason and Zuber (1962). The opposite results obtained by these authors could be attributed to the fact that their experiments were conducted under heat stress conditions, which would have impaired the synthesis of starch and amylose (Wilhelm et al., 1999). Heat stress decreases amylose and increases the overall proportion of amylopectin chains in maize and rice starch (Asaoka et al., 1984; Lu et al., 1996; Umemoto 


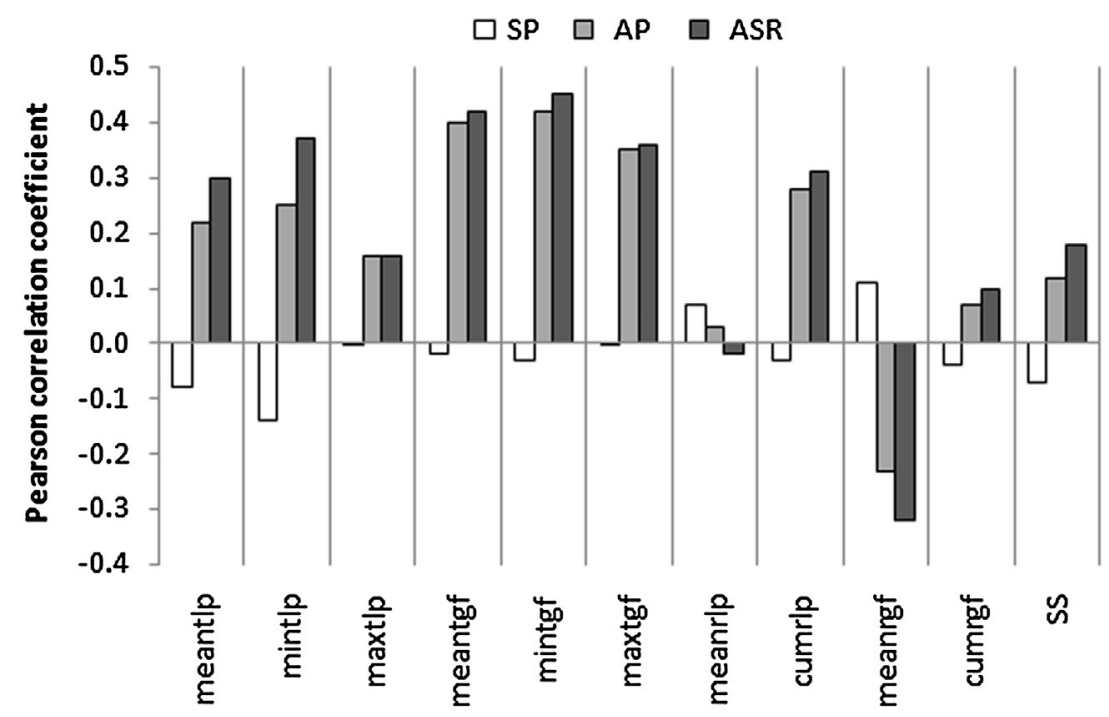

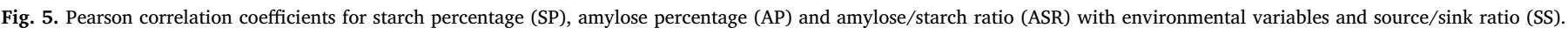

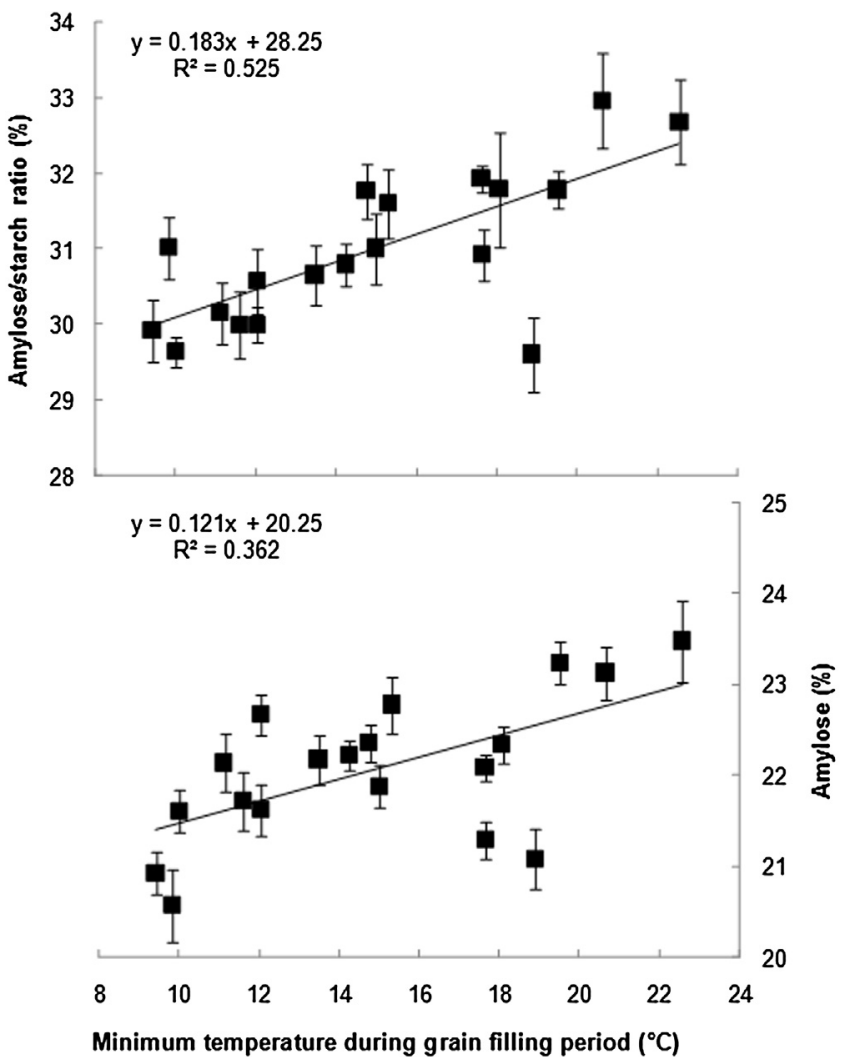

Fig. 6. Amylose percentage and amylose/starch ratio (expressed as percentage) as a function of minimum temperature during the effective grain filling period. Symbols represent average values of the three hybrids and bars indicate their standard error.

et al., 1999; Yamakawa et al., 2007). No heat stress conditions were evident in our experiment. Thus, increases in temperature during grain filling may increase amylose/starch ratio in maize as in this work, due to an effect on the starch branching enzyme. But if temperature rises to a thermal stress level, amylose/starch ratio may decrease due to the effect in other enzymatic steps as in previous.

Flint and semi-flint hybrids had high average amylose percentage and amylose/starch ratio in comparison with the semi-dent hybrid (Fig. 3). These differences could be explained by their different horny/ starchy endosperm proportion (Watson, 1987). Cell division in maize kernel ceases first in the central region of the endosperm and continues in the peripheral endosperm cells (Sass, 1977). Less mature cells in starchy endosperm, located in the central core, show a lower amylose content than cells in the surrounding horny endosperm (DombrinkKurtzman and Knutson, 1997). Thus, horny and starchy endosperms may have a different pattern of amylose and amylopectin accumulation during grain filling. However, in this work we observed that amylose/ starch ratio in hybrids with differences in kernel hardness presented a similar response to temperature during grain filling.

Changes observed in starch composition in this work could reduce wet milling performance, due to the increase in the difficulty in separating starch and gluten as amylose concentration rises (Anderson et al., 1960). Besides, increases in amylose concentration could markedly reduce the ruminal digestion kinetic and leave remaining starch reducing the digestion yield (Sandstedt et al., 1961; Witt et al., 2010). Maize grains with cero percent of amylose showed a digestion from around a $90 \%$, while maize with a 25 percent of amylose had a digestion from $70 \%$ (Sandstedt et al., 1961). Finally, to analyze how amylose/starch ratio ranges could affect the maize dry milling industrial process, we also need to consider other kernel variables as the protein and zein composition.

\section{Conclusions}

Kernel amylose percentage and amylose/starch ratio were affected by environmental conditions. Despite relative stable starch concentration in maize kernel, starch composition was affected by location and sowing date. Minimum temperature during effective grain filling period was the environmental factor that better accounted for those variations in starch composition. These results could help to understand the variables that affect starch content and composition for maize crops growing in different thermal regimes. Moreover, selecting a proper combination of hybrids and crop management practices, while taking into account meteorological conditions during grain filling, would allow us to obtain kernels with the desired starch composition. Results presented herein would help to reduce the uncertainty in obtaining a desirable maize kernel quality for either animal feed or industrial uses.

\section{Acknowledgments}

This research was supported by Instituto Nacional de Tecnología Agropecuaria (INTA PNCYO 1127042) and Universidad Nacional de Mar del Plata (UNMdP AGR 506/16 and AGR451/14). Authors wish to thank Diego Gaitan and Emiliano Veliz for technical assistance and 
Gloria Monterubbianesi for her valuable assistance in the statistical analysis.

\section{References}

Actis, 2007. Calidad industrial de maíz colorado duro para elaboración de "corn flakes": influencia del ambiente y el manejo del cultivo en el rendimiento de "flaking grits" y las propiedades térmicas del almidón. Tesis para obtener el grado de Magister Scientiae Facultad de Ciencias Agrarias, Universidad Nacional de Mar del Platapp. 171.

Anderson, R.A., Vojnovich, C., Griffin, E.L., 1960. Wet-milling high-amylose corn containing 49- and 57-percent-amylose starch. Cereal Chem. 37, 334-342.

Andrade, F.H., Otegui, M.E., Vega, C., 2000. Intercepted radiation at flowering and kernel number in maize. Agron. J. 92, 92-97.

Asaoka, M., Okuno, K., Sugimoto, Y., Kawakami, J., Fuwa, H., 1984. Effect of environmental temperature during development of rice plants on some properties of endosperm starch. Starch Stärke 36, 189-193.

Ball, S., Guan, H.P., James, M., Myers, A., Keeling, P., Mouille, G., Buleon, A., Colonna, P., Preiss, J., 1996. From glycogen to amylopectin: a model for the biogenesis of plant starch granule. Cell 86 (3), 349-352.

Beckles, D.M., Thitisaksakul, M., 2014. How environmental stress affects starch composition and functionality in cereal endosperm. Starch Stärke 66, 58-71.

Borrás, L., Curá, J.A., Otegui, M.E., 2002. Maize kernel composition and post-flowering source-sink ratio. Crop Sci. 42, 781-790.

Cantarero, M.G., Cirilo, A.G., Andrade, F.H., 1999. Night temperature at silking affects kernel set in maize. Crop Sci. 39, 703-710.

Chandrashekar, A., Mazhar, H., 1999. The biochemical basis and implications of grain strength in sorghum and maize. Cereal Sci. 30, 193-207.

Cirilo, A.G., Andrade, F.H., 1994. Sowing date and maize productivity: II. Kernel number determination. Crop Sci. 34, 1044-1046.

Cirilo, A.G., Andrade, F.H., 1996. Sowing date and kernel weight in maize. Crop Sci. 36, 325-331.

Cirilo, A.G., Masague, A., Tanaka, W., 2003. Influencia del manejo del cultivo en la calidad del grano de maíz colorado duro. INTA Pergamino. Revista de Tecnología Agropecuaria 8 (24), 6-9.

Cirilo, A.G., Actis, M., Andrade, F.H., Valentinuz, O.R., 2011. Crop management affects dry-milling quality of flint maize kernels. Field Crops Res. 122 (2), 140-150.

Commuri, P.D., Jones, R.J., 1999. Ultrastructural characterization of maize (Zeamays L.) kernels exposed to high temperature during endosperm cell division. Plant Cell Environ. 22, 375-385.

Dombrink-Kurtzman, M.A., Knutson, C.A., 1997. A study of maize endosperm hardness in relation to amylose content and susceptibility to damage. Cereal Chem. 74, 776-780.

Duarte, A.P., Mason, S.C., Jackson, D.S., Kiehl, J.C., 2005. Grain quality of Brazilian maize genotypes as influenced by nitrogen level. Crop Sci. 45, 1958-1964.

Dubois, M., Gilles, K.A., Hamilton, J.K., Rebers, P.A., Smith, F., 1956. Colorimetric method for determination of sugars and related substances. Anal. Chem. 28, $350-356$.

Eckhoff, S.R., 2004. Maize. wet milling. In: Wrigley, C., Corke, H., Walker, C.E. (Eds.), Encyclopedia of Grain Science. Elsevier, London, pp. 644-660 (225-241).

Eyhérabide, G.H., Robutti, J.L., Percibaldi, N.M., Presello, D.A., Alvarez, M., del, P., 2004 Association between grain yield and endosperm hardness in maize cultivars. Maydica 49, 319-326.

Fergason, V.L., Zuber, M.S., 1962. Influence of environment on amylose content of maize endosperm. Crop Sci. 2, 209-211.

Fischer, R.A., Byerlee, D., Edmeades, G.O., 2014. Crop Yields and Global Food Security: Will Yield Increase Continue to Feed the World? ACIAR Monograph No 158. Australian Centre for International Agricultural Research: Canberrapp. 634.

Fox, J., 2005. The r commander: a basic statistics graphical user interface to r. J. Stat. Softw. 14 (9), 1-42.

Hall, A.J., Rebella, C.M., Ghersa, C.M., Culot, J.P., 1992. Field-crops systems of the Pampas. In: Pearson, C.J. (Ed.), Field Crop Ecosystem. Elsevier, Amsterdam, pp.
$413-450$.

Hill, L., Paulsen, M., Bouzaher, A., Patterson, M., Bender, K., Kirleis, A., 1991. Economic Evaluation of Quality Characteristics in the Dry Milling of Corn 804. North Central Regional Publ. 330. Illinois Agricultural Experiment Station Bull.pp. 52.

Hurkman, W.J., Mccue, K.F., Altenbach, S.B., Korn, A., Tanaka, C.K., Kotharia, K.M., Johnson, E.L., Bechtel, D.B., Wilson, J.D., Anderson, O.D., Dupont, F.M., 2003. Effect of temperature on expression of genes encoding enzymes for starch biosynthesis in developing wheat endosperm. Plant Sci. 164, 873-881.

James, M.G., Denyer, K., Myers, A.M., 2003. Starch synthesis in the cereal endosperm. Curr. Opin. Plant Biol. 6, 215-222.

Jones, R.J., Schreiber, B.M.N., Roessler, J.A., 1996. Kernel sink capacity in maize: genotypic and maternal regulation. Crop Sci. 36, 301-306.

Knutson, C.A., 1986. A simplified colorimetric procedure for determination of amylose in maize starches. Cereal Chem. 63, 89-92.

Lenihan, E., Pollak, L., White, P., 2005. Thermal properties of starch from exotic-byadapted corn (Zea mays L.) lines grown in four environments. Cereal Chem. 82, 683-689.

Lu, T., Jane, J., Keeling, P.L., Singletary, G.W., 1996. Maize starch fine structures affected by ear developmental temperature. Carbohydr. Res. 282, 157-170.

Maddonni, G.A., Otegui, M.E., Bonhomme, R., 1998. Grain yield components in maize: II. Postsilking growth and kernel weight. Field Crops Res. 56, 257-264.

Nelson, D.W., Sommers, L.E., 1973. Determination of total nitrogen in plant material. Agron. J. 65, 109-112.

Pomeranz, Y., Traylor, D.D., Martin, C.R., Lai, F.S., 1984. Corn hardness determination. Cereal Chem. 61, 147-150.

Ritchie, S.W., Hanway, J.J., 1982. How a Corn Plant Develops. Ames, Iowa, Coop. Extension S., Iowa State Univ. of Science and Technologypp. 21.

Robutti, J.L., Borrás, F.S., Ferrer, M.E., Percibaldi, N.M., Knuston, C.E., 2000. Evaluation of quality factors in Argentine maize races. Cereal Chem. 77, 24-26.

Rooney, L.W., Pflugfelder, R.L., 1986. Factors affecting starch digestibility with special emphasis on sorghum and corn. J. Anim. Sci. 63, 1607-1623.

Sabelli, P.A., Larkings, B.A., 2009. The development of endosperm in grasses. Plant Physiol. 149, 14-26.

Sandstedt, R.M., Straham, D., Ueda, S., Abbot, R.C., 1961. The digestibility of highamylose corn starches compared to that of other starches: the apparent effect of the ae gene on susceptibility to amylase action. Cereal Chem. 39, 123-131.

Sass, J.E., 1977. Morphology, In: Sprague, G.F., (Ed.) Corn and Corn Improvement, 3rd edition, Am. Soc. Agronomy: Madison, WI, pp: 89-110.

Savin, R., Nicolas, M.E., 1999. Effects of timing of heat stress and drought on growth and quality of barley grains. Aust. J. Agric. Res. 50, 357-364.

Seebauer, J.R., Singletary, G.W., Krumpelman, P.M., Ruffo, M.L., Below, F.E., 2010. Relationship of source and sink in determining kernel composition of maize. J. Exp. Biol. 61 (2), 511-519.

Shi, Y., Seib, P.A., Bernardin, J.E., 1994. Effects of temperature during grain-filling on starches from six wheat cultivars. Cereal Chem. 71 (4), 369-383.

Tanaka, W., Cirilo, A., Ruiz, R., 2005. El manejo agronómico de maíz colorado afecta la calidad comercial del grano. In: Actas del 8 Congreso Nacional de Maíz. AIANBA ed. Rosario, Santa Fe, Argentina . 16-18 de Noviembre. pp. 67-70.

Umemoto, T., Nakamura, Y., Satoh, H., Terashima, K., 1999. Differences in amylopectin structure between two rice varieties in relation to the effects of temperature during grain-filling. Starch-Stärke 51, 58-62.

Watson, S.A., 1987. Measurement and maintenance of quality. In: Watson, S.A., Ramstad, P.E. (Eds.), Corn Chemistry and Technology. American Association of Cereal Chemists, St Paul, MN, pp. 125-183.

Wilhelm, E.P., Mullen, R.E., Keeling, P.L., Singletary, G.W., 1999. Heat stress during grain filling in maize: effects on kernel growth and metabolism. Crop Sci. 39, 1733-1741.

Witt, T., Gidley, M.J., Gilbert, R.G., 2010. Starch digestion mechanistic information from the time evolution of molecular size distributions. J. Agric. Food Chem. 58, 8444-8452.

Yamakawa, H., Hirose, T., Kuroda, M., Yamaguchi, T., 2007. Comprehensive expression profiling of rice grain filling-related genes under high temperature using DNA microarray. Plant Physiol. 144, 258-277. 